УДК 94(510).02

DOI 10.25205/1818-7919-2019-18-10-41-50

\title{
On the Nature of Cao Cao's Appointments of the Provincial Officials
}

\section{E. Borisov}

Novosibirsk State University

Novosibirsk, Russian Federation

Abstract

Later Han 後漢 termination in the $220 \mathrm{AD}$ was a result of multiple crises, one aspect of which had been the political bankruptcy of the emperor and his loyalists. A turbulent and war-torn period, which started from the rebellion of the Yellow Turbans in $184 \mathrm{AD}$, has been a topic of discussion for many years ever since the Jin 晉 empire. Although in the last years approaches to studies of the Later Han differ, there are three key historiographical ideas: the final years of the Later Han are discussed as a part of the Later Han, as a part of the Three Kingdoms era 三國 or are included into both periods. This case study is an attempt to show the possibility of a different approach and treat the period of 184-220 AD as a transition between Han and Wei empires, according to information about the local administrative appointments which can be found in the first chapter of San-guo zhi 三國志, being a biography of the most important statesman of this period - Cao Cao 曹操.The accounts, which can be found in his biography, indicate that Cao Cao's appointments did not precisely follow the traditions of the Later Han administrative system, but neither were they in full agreement with the ideas, which were later implemented during the Wei-Jin Nan-beichao period. His conduct was much more pragmatic than that of other Later Han statesmen, but he never ventured as far as his successors did in granting too much power to the local gentry.

Keywords

Later Han, Three Kingdoms, San-guozhi, Cao Cao, Provincial appointments, Transition Period

For citation

Borisov D. E. On the Nature of Cao Cao's Appointments of the Provincial Officials. Vestnik NSU. Series: History and Philology, 2019, vol. 18, no. 10: Oriental Studies, p. 41-50. DOI 10.25205/1818-7919-2019-18-10-41-50

\section{О характере назначений на посты провинциального уровня при Цао Цао}

\section{Д. Э. Борисов}

\section{Новосибирский государственный университет}

Новосибирск, Россия

Аннотация

Конец империи Поздняя Хань 後漢 в 220 г. н. э. явился результатом затяжного кризиса. Одним из наиболее важных факторов, действовавших в период со 189 по 220 г. н. э., было политическое банкротство правящего режима. Бурный период, наполненный политическими коллизиями и военными действиями, начавшимися после восстания «Желтых повязок» в 184 г., активно обсуждался китайскими историками начиная с правления империи Цзинь 晉. Как древняя и средневековая, так и современная историография не имеют единого мнения об этом времени: оно рассматривается и в рамках истории Поздней Хань, и как часть Троецарствия 三國 или же периода Вэй-Цзинь Нань-бэйчао 魏晉南北朝. Данное исследование выполнено на материалах первой гла- 
вы хроники “Саньго чжи” 三國志 - истории жизни наиболее видного деятеля рассматриваемого периода Цао Цао 曹操 - и является попыткой продемонстрировать иной подход к существующей проблеме. По результатам анализа назначений глав округов, областей и уездов, осуществленных Цао Цао, автор предлагает выделить время его военного правления в качестве переходного периода между империей Хань 漢 и царством Вэй 魏.

Ключевые слова

Поздняя Хань, Троецарствие, Сань-го чжи, Цао Цао, окружные назначения, переходный период

Для ичитирования

Борисов Д. Э. О характере назначений на посты провинциального уровня при Цао Цао // Вестник НГУ. Серия: История, филология. 2019. Т. 18, № 10: Востоковедение. С. 41-50. (in Eng.) DOI 10.25205/1818-7919-2019-18$10-41-50$

Scholars hold to the different ideas when it comes to the discussion of Wei-Jin Nan-beichao 魏 晉南北朝 transition period. The traditional historiography of China has always been fluctuating between a neutral attitude to the events of the past and condemnation of some decisions, actions or even personalities in a most ruthless way. The most notorious example can be found in the difference between the historical work of Sima Guang ${ }^{1}$ 司馬光 and the philosophical work of Zhu $\mathrm{Xi}^{2}$ 朱喜. While the first tried to compile a coherent account by searching through the available sources of his time and arranging them in chronological order, the second tried to apply ideas of philosophy and supply most of the events, which were listed by Sima Guang, with the idea of the Mandate of Heaven and connected with it philosophical explanations of historical facts. The result was that his explanations were more powerful and acceptable for the ruling dynasty of his time, but his influence and ideas distorted the overall picture to such a degree that his Zi-zhi tong-jian gang$m u$ is less reliable as a historical source than that of his predecessor, Sima Guang [de Crespigny, 1973. p. 66].

The traditional view on the historiography, which was concentrated on the dynastic cycles and necessity for an explanation of the legitimization of the contemporary ruling dynasty has been dominant throughout Chinese history, at least until the modern times, but it was not left unchallenged. In fact, the first attempt to reconsider this approach was made during the Tang dynasty by Liu Zhiji ${ }^{3}$ 劉知幾. Although he did not suggest any new ideas or forms how to write the dynastic histories, his work is still considered as a very important stage of the historiographical evolution, since Liu Zhiji was heavily emphasizing the necessity of knowledge about the used sources, application of the skeptical approach towards the existing material and stressed the essential role of the evidence for discussion of historical facts written in the source [Liu Zhiji, Liu Zhan, 2010].

One of the periods, which has been addressed many times by Chinese medieval and modern historians is the Wei-Jin Nan-beichao transition. It is a notorious period, which is considered by many Soviet and Russian scholars to be a change towards the medieval China [Варенов и др., 2016. С. 204; Комиссаров и др., 2017. С. 30-31]. Although Chinese, Japanese and Western scholars are not agreed in the perception of this transition period ${ }^{4}$, it is important to point out that it is agreed

\footnotetext{
${ }^{1}$ Sima Guang 司馬光, style Junshi 君實 (1019-1086), was a scholar, statesman and poet during the existence of the Northern Song (960-1126). He is especially famous for compiling his historical work Zi-zhi tong-jian 資治通鑒 “Comprehensive Mirror for aid in Government".

${ }^{2} \mathrm{Zhu} \mathrm{Xi}$ 朱喜, style Yuanhui 元晦 (1130-1200), was a philosopher, scholar, statesman during the existence of the Southern Song (1127-1279). His philosophical system had been dominant within Chinese society until the end of the 19th century. He also revised the Zi-zhi tong-jian and created Tong-jian gang-mu 通鑒網目 “Outline and Digest of the General Mirror" - a more philosophically oriented piece of work.

${ }^{3}$ Liu Zhiji 劉知幾, style Zixuan 子玄 (661-721), was an official scholar and historian during the existence of the Tang empire (618-907). He is famous for writing historiographical study Shi-tong 史通 “Historical Perspectives", which can be considered to be the first comprehensive work on historical criticism in any language. // Encyclopedia Britannica. Historiography. Retrieved February 8, 2018, from: https:/www.britannica.com/topic/historiography\#ref523919

${ }^{4}$ While Japanese and Chinese works usually treat Wei-Jin Nan-beichao as a shift from the Imperial rule model towards the rule of the Aristocratic clans, professor Albert E. Dien advocated in his works caution towards using such an approach [Dien, 1990. p. 28].
} 
that the beginning of this period dates back to $220 \mathrm{AD}$ - the official date of the termination of the Han empire, or rather an abdication of its last emperor Xian-di ${ }^{5}$ 獻帝. We can accept an even earlier date $-189 \mathrm{AD}$, when the Han institutions were thrown into a deep crisis. While it is discussible when did it begin - with the activities of Liang $\mathrm{Ji}^{6}{ }^{6}$ 梁冀, the rule of Shun-di ${ }^{7}$ 顺帝 and Huan-di ${ }^{8}$ 桓帝, or with the rebellion of the Yellow Turbans - we can safely assume that after 189 AD the imperial court and the emperor became politically bankrupt - they existed only as a symbol and although official procedures were carried out, nevertheless they were only rituals, since the mechanisms of bureaucracy of the Later Han remained intact, but were no longer working as intended.

After the political situation of the Later Han became chaotic, there appeared warlords who started to fight each other for dominance in the Central plain region, Sichuan basin and southern parts of China. One of the most important statesmen who emerged on top of this chaos creating a measure of stability in his territory was Cao Cao 曹操 - self-appointed governor of the Yanzhou 充 州 province. In $196 \mathrm{AD}$ Cao Cao had convinced Xian-di to leave the burnt ${ }^{9}$ capital territory for his own more or less developed and stable region. After a short period of political intrigue and some mistakes, Cao Cao assumed the post of the Excellency of works ${ }^{10}$ 司空 and had only some minor opposition ${ }^{11}$ in charge of the imperial government, while also controlling an army, which was considered to be the Han army, but was funded by and was loyal to Cao Cao only.

One of the most perplexing things nowadays is that we have no generally accepted idea of how to treat this small period of the puppet Han state between the Dong Zhuo ${ }^{12}$ 董卓 take over and the official abdication of Han. Cao Cao and Xian-di were locked together, and such a situation, ironically, was always supported by philosophical ideas of the Confucius - the Ruler was not controlling the situation at all and was kept only as a tool to communicate with the Heaven and ancestors, while an influential counselor and the court were charged with control of the matters of the state. Although Xian-di, presumably, tried to break free from the control of Cao Cao, it is important to remember that the position of the Han emperor was no better than the position of the kings of the Zhou dynasty during the Chunqiu-Zhanguo period 春秋戰國. Since the proposal of Liu

\footnotetext{
${ }^{5}$ Liu Xie 劉協, style Bohe 伯和 (181-234), was the last emperor of the Later Han period. He had been a puppet emperor during all of his reign, which lasted from 189 to $220 \mathrm{AD}$ and ended with his abdication.

${ }^{6}$ Liang Ji 梁冀, style Bozhuo 伯卓 (?-159), brother to the empress Liang 梁, who established hegemony of the Liang clan over the bureaucracy of the Later Han after the deaths of the emperors Shun-di and Chong-di. He is shown as a cruel and extravagant person in his conducts.

${ }^{7}$ Liu Bao 劉保 (125-144), more known as the emperor Shun-di, was enthroned through eunuch's coup against the Yan clan. His reign is usually described as the last traditional rule, when the emperor was a part of the traditional Confucian bureaucratic system. He created a huge gap in political power between the consort families and officials at the court and died young.

${ }^{8}$ Liu Zhi 劉志 (146-168), more known as the emperor Huan-di, was enthroned through eunuch's coup against the Liang clan. His reign is associated with the increased political power of the eunuchs and decay of trust from the officials at the court to the regime. He is often blamed for the decline of the Later Han.

${ }^{9}$ On the account of the destruction of the capital see [de Crespigny, 2017. p. 456-461]. In Russian see [Борисов, 2015b, C. 57; 2016. C. 138-141].

${ }^{10}$ Hereinafter we use the translations and titles which are used by professor R.R.C. de Crespigny, since his system is in our view more accurate concerning the end of the Later Han.

${ }^{11}$ Although the title of Excellency gave Cao Cao legitimization for most of his actions, this post still did not give him full control [Bielenstein, 1980. p. 15]. Country was in a state of constant turmoil and even with the ministers appointed, the government didn't have enough power to control the situation. It was a complex situation worth of a special investigation and is not a point of focus of the current case study.

${ }^{12}$ Dong Zhuo 董卓, style 仲颖 (?-192) was a fighting man from Longxi, who distinguished himself in campaigns against the qiang tribes. His early career is that of an able commander, who was looking out for his forces, but his account is distorted due to his later conduct, when he deposed the emperor Shao-di and took control over the government.
} 
Yan ${ }^{13}$ to reconstitute the post of Governor 牧 and allow them to rule the territory they would be entrusted with, the court virtually withdrew some territories from the direct control of the central government, and new "owners" were reluctant to pay tribute or support the Han, which was in a constant crisis after the dethronement of Shao-di ${ }^{14}$ 少帝.

The situation started to change gradually after Cao Cao had welcomed the emperor to his base of operations. Cao Cao obtained control of the imperial court by placing his trusted followers into critical positions or by winning over officials who had been serving Xian-di before. Being able to produce "imperial edicts" after this, Cao Cao now had a legal backbone to his conquests and border sorties. His family and distant relatives were in control of the army, and most of his forces before $196 \mathrm{AD}$ were in a state of a constant war with neighboring warlords. Therefore, his force was united and experienced both in civil and military matters, while people, whom Cao Cao trusted, were put in control. However, annals of Cao Cao from San-guo zhi show a different approach to the appointments of the provincial officials ${ }^{15}$.

When it comes to recruiting procedures of the officials of the Later Han, the sources, especially biographies, give a vague, but understandable "Recommendation system" 察舉征辟制 which had been used for a long time during the Han dynasty ${ }^{16}$. The basic idea of this structure was that the provincial officials were to recommend dutiful and moral men to the court, and after a short period of probation, they were usually granted a post. If an appointee was able to fulfill his duties and was praised for his deeds, the court might have bestowed a promotion ${ }^{17}$. Leaders of districts were under strict rules when they were appointed to their post: they or their family could not have connections or be registered at the location they would work at. Most of the duties of the Inspectors 刺史, Chancellors 相, and Administrators 太守 were focused on reports and censorship. The Governor post had been abolished at the beginning of the Later Han and reinstituted after the Yellow Turbans rebellion, and it had mostly the same responsibilities as that of an Inspector. However Governors were not restricted to non-acting and could actually exercise legislative power, while Inspectors were prohibited from doing so and were to report to the court and await for the decision from the capital. There were exceptions to this rule [de Crespigny, 2007. p. 1228]. Magistrates of the counties were tasked with overwhelming responsibilities of enforcing law and order in the prefectures, supervising the people in their seasonal work, storing grain as a precaution against famine, registering people and property, collecting taxes, mobilizing the people for corvee, supervising public works, performing rituals, keeping schools, promoting the worthy, and judging criminal and civil cases [Bielenstein, 1980. p. 99-100].

During his work, Cao Cao was using the "Recommendation system" ${ }^{18}$, however, he gradually shifted from it. The "Recommendation system" had been criticized before and during the hegemony of Liang Ji and an experiment with exams as a new way to enter the official office was proposed. However, this idea did not come to fruition. Cao Cao did not have time for experiments and

\footnotetext{
${ }^{13}$ Liu Yan 劉焉, style Junlang 君郎 (?-194), member of the imperial clan, but from a junior lineage. He held different important official posts during the reign of Ling-di. After the Yellow Turban rebellion Liu Yan was appointed to the post of Governor of Yizhou 益州 province. After establishing control over the region, Liu Yan found himself separated from the Western capital Chang'an 長安 by Zhang Lu 張魯 and Zhang Xiu 張脩, but was not eager to break through and instead acted as a de-facto ruler of the Sichuan basin.

${ }^{14}$ Emperor Ling-di had two sons - one from his principal wife (the elder son Liu Bian 劉辯) and another from his favorite concubine (the second son). His wife, Lady He, was jealous and poisoned the concubine. Empress-dowager Dong (the mother of Ling-di) took care of her second grandson, who will become future Xian-di. After a warlord from Liangzhou 涼州 province Dong Zhuo 董卓, and his qiang troops overtook the capital, he quickly dethroned Shao-di and killed Empress He, thus starting a wide-spread rebellion against him in China.

${ }^{15}$ In this case study we are focusing only on the governors, administrators, chancellors and magistrates, which were appointed by $\mathrm{Cao} \mathrm{Cao}$

${ }^{16}$ For a discussion about the "Recommendation system" and the nine rank system, see [Wang Pei, 2017. p. 55-60].

${ }^{17}$ See, for example, the beginning of the career of Сао Саo himself: [Борисов, 2015a. С. 46-48].

${ }^{18}$ On the "Recommendation system" of the Later Han, see "Recruitment revisited" [de Crespigny, 2008. p. 1-46].
} 
probably relied on his raw experience in this matter. After his death, one of his trusted officials, Chen Qun 陳㩔, introduced a nine rank system to his son, Cao Pi. This system was simple and different from the previous idea of the Later Han, and it included the practical approach of Cao Cao. It was not perfect regarding corruptness ${ }^{19}$ - the practice would prove that the appointees were direct representatives of the local communities, but most of them were members of the local gentry, which were slowly pushing away imperial rule. Nevertheless, this system provided a constant stream of officials - which was a very significant result, since during the previous 30 years of the Later Han, men of ability refused to receive appointments and were sabotaging the rejuvenation of the enormous bureaucratic apparatus [de Crespigny, 2010. p. 247-250].

It was, of course, not only the result of Cao's experiences that created the idea of the nine rank system. The Later Han was searching for an answer to this problem long before him, but his activities were a catalyst to a slow process of shifting from traditional evaluation of an appointee in terms of "pure speech" or "judgement of character" towards a more practical approach of evaluating talents and giving an appicant duties and responsibilities according to his abilities. Most of the appointments, which Cao Cao had done, were the result of his evaluation of a person, whether this would be his military talent or his loyalty. The nine rank system's innovation was a post of a Rectifier 中正, which would overtake a responsibility of the district leader, and evaluate recommendation and place a nominee into one of the nine ranks. The Rectifiers were appointed by the court and were to report only directly to the court. Cao Cao's actions resemble that of the Rectifier, but on a larger scale, and he also did not have a ranking system, but was only evaluating talents of the nominees and giving them posts, which he considered to be appropriate.

This case study is based only on the biography of Cao Cao, which is the first chapter of Sanguozhi. There are 20 cases of appointments of provincial officials, found in the first chapter of San-guo zhi ${ }^{20}$. Most of them had been instated directly by Cao Cao, and usually had an explanation for his decision. They are also connected to the administrative changes - whether it is an inclusion of a new territory into Cao's sphere of influence, abolishment of an existing one or creation of a new district. Some of the cases lack details of the appointment, but they, nevertheless, inform us about the activities of the appointed official, which serves as a plausible way to discern whether or not Cao's approach to appointments was valid or not during this chaotic time.

When it comes to the appointments done directly by Cao Cao, San-guo zhi is always clear about his motivation and reasoning. Sometimes the commentaries of Pei Songzhi 裴松之 give more information, but they usually support the main problem which Cao Cao had been facing throughout his career - he had to appoint people of ability, but kept in mind the interests of the gentry and also kept tight control of the imperial court. It is also clear that he was concerned about making compromises with literary men and scholars. Among those, who we are certain were appointed by Cao Cao, are Bi Chen 畢諶, Wei Chong 魏種, Gao Gan 高幹, Yang Qiu 楊秋, Wen Ping 文聘, Guanqiu Xing 曲丘興, Dongli Bao 東里墪, Zang Ba 蔵霸. They were appointed at different times, and circumstances of their enrollment into Cao's force are different, but they all had something that Cao admired.

Bi Chen and Wei Chong, both members of Cao Cao's staff at the beginning of his career, were admired for their talents, and the affection Cao had for them saved them from execution [Chen Shou, Pei Songzhi, 2013. p. 13]. Yang Qiu and Wen Ping, generals from Liangzhou and Jingzhou respectively, both surrendered and were given important jobs of pacifying and guarding the region they

\footnotetext{
${ }^{19}$ One of the main changes to the ways of entering the office was done during the Later Han - introduction of the sellable posts, which would later equate to bribery. R.R.C. de Crespigny has been discussing these as "fines" in [de Crespigny, 1966. p. 67-78], however Carl Leban opposed this theory in [Leban, 1990. p. 31-47].

${ }^{20}$ The Records of the Three Kingdoms, written during the rule of the Jin Empire, is one of the primary source materials for the research of the end of the Later Han period and the Three Kingdoms. The structure of the sources is different from the dynastic histories and the version without later commentaries is cryptic at some biographies. It was designed as means to justify the rule of Jin, so it also gave Wei dynasty position as a successor to the Later Han. In 429 it was edited by Pei Songzhi 裴松之, and it was endorsed by the throne as an official history under the title "San-guo zhi".
} 
were familiar with - this is something that would not have been done in the Later Han [Chen Shou, Pei Songzhi, 2013. p. 22, 27]. Usually, both civil and military officials were appointed to the regions they would not be accustomed to, to prevent the formation of any cliques. For Cao, it was different and in the case of Wen Ping he has even allowed the latter to keep command of his troops at the time of surrender.

In the case of Gao Gan it was a far-sighted decision - he was a relative of Yuan Shao and had been guarding the eastern flank of Shao's forces, but when it became obvious that the hegemony of the Yuan clan in the north was finished, Gao Gan made a formal surrender to Cao Cao [Chen Shou, Pei Songzhi, 2013. p. 20-21]. Appointed afterward as an Inspector, instead of his previous position of Governor, Gao Gan was stripped of the authoritative control of his previously own region, felt insecure and rebelled, but was swiftly dealt with and later another person - Wang Yan was given a promotion for capturing and beheading Gao Gan, while he tried to flee through the capital region [Chen Shou, Pei Songzhi, 2013. p. 21].

Guanqiu Xing, the father of a famous general Guanqiu Jian 曲丘儉 of the Wei kingdom, had a long and fruitful career in the north-western borders, where he started as an Administrator of the Anding commandery and was personally entrusted by Cao Cao to handle the affairs of non-Chinese qiang and $h u$ tribes [Chen Shou, Pei Songzhi, 2013. p. 31]. After his successes, he was promoted to the post of Administrator of Wuwei, and later, during the Three Kingdom speriod, he became a Court architect of Wei. Cao Cao gave a personal speech to Guanqiu Xing, which was recorded and he instructed Xing in the way he should act at his post. Unfortunately, the information about Guanqiu Xing's previous office is lacking, all we know is that he hailed from the Hedong commandery, but it is certain that Cao's estimation of Xing's abilities as a controller for the nonChinese tribes was accurate and efficient.

The case of Dongli Bao shows a slightly different situation regarding official appointments when it comes to the importance of civil and military posts [Chen Shou, Pei Songzhi, 2013. p. 37-38]. Bao was appointed as an Administrator of Nanyang commandery 南陽 - the central trading hub of Cao's territory, which was also very crucial for holding the roads which led to Xuchang, Chang'an and Luoyang. It is arguable who exactly appointed Bao to such a crucial position since we lack the details of his official career during Cao Cao's militaristic regime, but it is probable that Cao had knowledge of this appointment and did not oppose it. Dongli Bao was unable to stop the mutiny led by the garrison commander Hou Yin. However, he managed to escape from the city and rally the remaining loyal forces. Afterwards, he laid a siege to the rebellious city and secured the roads to Jingzhou, so Hou Yin could not communicate with Guan Yu. After the city was retaken, Dongli Bao was assigned as a major to the army general Yu Jin. During the Later Han, such a situation would have been considered a demotion, but the militaristic regime of Cao Cao was centered around the army, so we may agree with de Crespigny's assumption, that this was a reassessment of Bao's talents in promoting him in the military ranks [de Crespigny, 2007. p. 160].

The case of Zang $\mathrm{Ba}$ is connected to the defeat of Lü Bu in the Qingzhou and Xuzhou provinces - the third and the last campaign, after which these territories were finally conquered and "pacified" [Chen Shou, Pei Songzhi, 2013. p. 12-13]. In the first chapter of San-guo zhi, it is unclear about the actions Cao Cao had done, but the biography of Zang Ba in the 18th chapter sheds some light on his career. Being a representative of the local gentry, Zang Ba became known after he, with the help of some retainers of his family, freed his father from the jurisdiction of the local administrator. Afterwards, during the Yellow Turbans rebellion, he helped inspector Tao Qian 陶谦, but left his service and created a bandit organization in the mountains. He kept a loose alliance with $\mathrm{Lü} \mathrm{Bu}$, after his defeat was captured, but treated with respect, and Cao Cao entrusted him with control over his newly acquired region and even rearranged the territories and gave separated counties to Zang Ba's subordinates. It is important to point out that Zang Ba had no connection with Cao previously, and he resisted his control, but, after his submission, he was appointed and left in control. The reason behind this action of Cao Cao might be that Zang Ba was popular among the local gentry and was acceptable as a leader of this territory. Cao had come in force to Qingzhou and Xuzhou multiple times, and now he was seeking someone who could keep the peace for this region, 
and Zang Ba did exactly that. Moreover, he was not only entrusted with civil administration, but, as we can find in his biography, he simultaneously held command of the army and was acting as a military general, bringing his army outside of the borders of his commandery and battling Sun Quan's forces [Chen Shou, Pei Songzhi, 2013. p. 369-370].

Another vital aspect of Cao's arrangement of provincial officials is the way he treated the necessity of separate administration for each region he controlled. While he did not try to rework the bureaucratic system as a whole (he only tried to mimicry the official court of the Later Han when he was enfeoffed as a Duke of Wei), he was ready to create new units and abolish old ones ${ }^{21}$. For each of the cases, the annals of Cao explain the situation, and most of the time we can trace officials, who were involved in the new units, although they are not explicitly pointed out in Cao's biography. One of the examples is the creation of Xinxing commandery 新興郡- a new unit, which was a result of the abolishment of the commanderies of Yunzhong 雲中, Dingxiang 定襄, Wuyuan 五原 and Shuofang 朔方, and replacement of each commandery 郡 with a single county 縣, uniting them all under the new district [Chen Shou, Pei Songzhi, 2013. p. 33]. The reason behind it is the destruction of the discussed region - it was abandoned to the raids led by xiongnu and xianbei during this chaotic era. The total amount of Chinese inhabitants dropped, and an extensive administration, which had been working before was no longer necessary. Cao Cao was working towards an efficient administrative system, and it was needless to keep a significant structure where it was no longer needed - that also goes for the districts, which he splitted in case they were not pacified and, vice versa, united them if the immediate danger to the territory was eliminated. Another essential point that Cao made concerns the appointment of $\mathrm{Du} \mathrm{Hu}$ 杜濩 and $\mathrm{Fu} \mathrm{Hu}$ 朴胡, two non-Chinese tribe leaders, who were appointed as administrators after they made a formal surrender with their clans and territories [Chen Shou, Pei Songzhi, 2013. p. 33]. Cao Cao did not appoint his administrator at that time, but granted marquisates to these tribesmen and also granted them control over the region they had surrendered - something that would not have been done during the Later Han times when the territories with barbaric tribes were usually supervised by the Chinese officials.

The accounts, which can be found in his biography, indicate that Cao Cao's appointments did not precisely follow the traditions of the Later Han administrative system, but neither were they in full agreement with the ideas, which were later implemented during the Wei-Jin Nan-beichao period. Cao had been acting as a Rectifier 中正, but on a grander scale - he measured the talents of his appointees, their loyalty, and filial piety, trying to find a necessary capacity in people to deal with the surrounding troubled time. He was also interested in those, who were versed in classics or were famous scholars of the time, but they were usually placed in charge of the Later Han court or in the administration of the regions, which were pacified and were in a stable position for some time. The military regime needed control and a stable line of supplies for the army, but at the same time a scholarship was praised by the Cao family, so a delicate compromise had been maintained - Cao Cao would employ representatives of the gentry, but he always placed abilities of the appointee before his standings in the community. Another aspect can be seen in Zang Ba's appointment - he was a bandit leader, but was known and probably sponsored by the local gentry of the region, since he was in a position to even rival the administrator of Langye with his band.

The appointments and the appointed provincial officials, which were recorded in this source give us a different picture from the Hou-Han shu's 后漢書 treatises 志 or biographies sections, which deal with the rest of the Later Han. To further investigate the situation and confirm the idea that the military regime of Cao Cao should be treated as a separate transition period between Han empire and the Wei-Jin Nan-beichao, other biographies of essential officials in San-guo zhi should be

\footnotetext{
${ }^{21}$ For a general understanding of the administrative geography, see a short summary in the "A Biographical Dictionary of Later Han to the Three Kingdoms" [de Crespigny, 2007. p. 1193-1215].
} 
analyzed and verified against similar accounts in the Dong-guan Hanji ${ }^{22}$ 東觀漢記 “Han Records of the Eastern pavilion" or Hou-Han shu. It is evident that since the rise of Dong Zhuo the situation of the Later Han was chaotic and unstable and local warlords were in constant search for answers to the challenges of their time and those who were not ready to adapt and change their ways were destroyed or conquered. Cao Cao's appointments look chaotic and lacking any system, but they reflect the fact that he was trying to find and promote able and active persons who could cope with problems arising in the situation of permanent emergency. This character of appointments could be looked at as transitional one from the Later Han "Recommendation system" to the nine rank system adopted by Cao Cao's successors. Cao's activities as a minister catalyzed many changes within society, the military, and even agriculture, but it was people, whom he appointed to relevant posts, not only him alone, who contributed to the transitional state of his military regime.

\section{References}

Bielenstein Hans. The bureaucracy of Han times. New York, Cambridge University Press, 1980, $276 \mathrm{p}$.

Borisov D. E. The biography of Cao Cao: at the crossroads. Emperor Lin's death and Dong Zhuo's takeover (188-189 A.D.). Vestnik NSU. Series: History, Philology, 2015b, vol. 14, no. 10: Oriental Studies, p. 54-61. (in Russ.)

Borisov D. E. The biography of Cao Cao: early years. His origin, youth and the beginning of the career (155-187 A.D.). Vestnik NSU. Series: History, Philology, 2015a, vol. 14, no. 4: Oriental Studies, p. 43-52. (in Russ.)

Borisov D. E. The biography of Cao Cao: Change of fate. The uprising of "loyal rebels" and disintegration of their camp (190-192 A.D.). Vestnik NSU. Series: History, Philology, 2016, vol. 15, no. 4: Oriental Studies, p. 137-146. (in Russ.)

Chen Shou, Pei Songzhi. Sanguozhi [陈寿, 裴松之。三国志。湖南: 岳麓书社]. The Records of the Three Kingdoms. Hunan, Yuelushushe, 2013, vol. 1, 508 p. (in Chin.)

Crespigny R. R. C., de. Fire over Luoyang: a history of the Later Han dynasty, 23-220 AD. Leiden, Brill, 2017, $580 \mathrm{p}$.

Crespigny R. R. C., de. Imperial Warlord. Leiden, Brill, 2010, 555 p.

Crespigny R. R. C., de. Recruitment Revisited: the Commissioned Civil Service of Later Han. Early Medieval China, 2008, iss. 2, p. 1-47.

Crespigny R. R. C., de. Universal Histories. In: Essays on the Sources for Chinese History. Canberra, 1973, p. 64-70.

Crespigny R. R. C., de.A Biographical Dictionary of Later Han to the Three Kingdoms (230 220 A.D.). Leiden, Brill, 2007, 1312 p.

Crespigny R. R. C., de.The Recruitment System of the Imperial Bureaucracy of Later Han. The Chung Chi Journal, 1966, vol. 6, iss. 1, p. 67-78.

Dien, Albert E. Introduction. In: State and Society in Early Medieval China. Hong Kong University Press, 1990, p. 1-29.

Komissarov S. A., Soloviev A. I., Nikolaeva N. Sh. China's transition from Antiquity to the Middle Ages (according to archaeological data). Vestnik NSU. Series: History, Philology, 2017, vol. 16, no. 4: Oriental Studies, p. 30-35. (in Russ.)

Leban Carl. Sale of Offices or "Fines" in the Later Han: A Matter of Interpretation. In: State and Society in Early Medieval China. Hong Kong University Press, 1990, p. 31-47.

\footnotetext{
${ }^{22}$ Dong-guan Hanji 東觀漢記 “Han Records of the Eastern pavilion”- partly lost alternative history of the Later Han, which was compiled during the existence of the Later Han. Most of this work did not survive, and only quotations in other sources remain.
} 
Liu Zhiji, Liu Zhanzhao. Shitong pingzhu [劉知幾,刘占召。史通評註。北京: 中国编译出版社]. Notes and commentary on the "Historical Perspectives". Beijing, Zhongguobianyichubanshe, 2010, 522 p. (in Chin.)

Varenov A. V., Borisov D. E., Ibragimova R. R. Burial constructions of Eastern Han and Three Kingdoms and the problem of transition from late Antiquity to early Middle Ages according Chinese archaeology. Vestnik NSU. Series: History, Philology, 2016, vol. 15, no. 4: Oriental Studies, p. 204-218. (in Russ.)

Wang Pei. Debates on Political Meritocracy in China: A Historical Perspective. Philosophy and Public Issues - The China Model: Political Meritocracy and the Limits of Democracy, 2017, vol. 7, iss. 1, p. 53-71.

\section{Список литературы}

Борисов Д. Э. Биография Цао Цао: ранние годы. Происхождение, юность и начало карьеры (155-187 годы н. э.) // Вестник НГУ. Серия История, филология. 2015a. Т. 14, № 4: Востоковедение. С. 43-52.

Борисов Д. Э. Биография Цао Цао: на перепутье. Смерть императора Лин-ди и переворот Дун Чжо (188-189 годы н. э.) // Вестник НГУ. Серия История, филология. 2015b. Т. 14, № 10: Востоковедение. С. 54-61.

Борисов Д.Э. Биография Цао Цао: перемена участи. Восстание лоялистов и развал лагеря повстанцев (190-192 годы н.э.) // Вестник НГУ. Серия История, филология. 2016. Т. 15, № 4: Востоковедение. С. 137-146.

Варенов А. В., Борисов Д.Э., Ибрагимова Р. Р. Погребальные конструкции Восточной Хань и Троецарствия и проблема перехода от поздней древности к раннему средневековью по данным китайской археологии // Вестник НГУ. Серия: История, филология. 2016. Т. 15, № 4: Востоковедение. С. 204-218.

Комиссаров С. А., Соловьев А. И., Николаева Н. Ш. О характере перехода от Древности к Средним Векам на территории Китая (по данным археологии) // Вестник НГУ. Серия: История, филология. 2017. Т. 16, № 4: Востоковедение. С. 30-35.

Bielenstein Hans. The bureaucracy of Han times. New York, Cambridge University Press, 1980, $276 \mathrm{p}$.

Chen Shou, Pei Songzhi. Sanguozhi [陈寿, 裴松之。三国志。湖南: 岳麓书社]. The Records of the Three Kingdoms. Hunan, Yuelushushe, 2013, vol. 1, 508 p. (in Chin.)

Crespigny R. R. C., de. Fire over Luoyang: a history of the Later Han dynasty, 23-220 AD. Leiden, Brill, 2017, $580 \mathrm{p}$.

Crespigny R. R. C., de. Imperial Warlord. Leiden, Brill, 2010, 555 p.

Crespigny R. R. C., de. Recruitment Revisited: the Commissioned Civil Service of Later Han. Early Medieval China, 2008, iss. 2, p. 1-47.

Crespigny R. R. C., de. Universal Histories. In: Essays on the Sources for Chinese History. Canberra, 1973, p. 64-70.

Crespigny R. R. C., de.A Biographical Dictionary of Later Han to the Three Kingdoms (230220 A.D.). Leiden, Brill, 2007, 1312 p.

Crespigny R. R. C., de.The Recruitment System of the Imperial Bureaucracy of Later Han. The Chung Chi Journal, 1966, vol. 6, iss. 1, p. 67-78.

Dien, Albert E. Introduction. In: State and Society in Early Medieval China. Hong Kong University Press, 1990, p. 1-29.

Leban Carl. Sale of Offices or "Fines" in the Later Han: A Matter of Interpretation. In: State and Society in Early Medieval China. Hong Kong University Press, 1990, p. 31-47. 
Liu Zhiji, Liu Zhanzhao. Shitong pingzhu [劉知幾,刘占召。史通評註。北京:中国编译出版社]. Notes and commentary on the "Historical Perspectives". Beijing, Zhongguobianyichubanshe, 2010, 522 p. (in Chin.)

Wang Pei. Debates on Political Meritocracy in China: A Historical Perspective. Philosophy and Public Issues - The China Model: Political Meritocracy and the Limits of Democracy, 2017, vol. 7, iss. 1, p. 53-71.

Материал поступил в редколлегию

\section{Сведения об авторе}

Борисов Дмитрий Эдуардович, аспирант, кафедра востоковедения, Новосибирский государственный университет (ул. Пирогова, 1, Новосибирск, 630090, Россия)

borisov.dmitriy@protonmail.com

\section{Information about the Author}

Dmitriy E. Borisov, post-graduate student, Chair of Oriental Studies, Novosibirsk State University (1 Pirogova str., Novosibirsk, 630090, Russia)

borisov.dmitriy@protonmail.com 